\title{
First ultrastructural evidence of placental nutrition in a ctenostome bryozoan: example of Amathia verticillata
}

\author{
Thomas Schwaha ${ }^{1}(1) \cdot$ Martin Moosbrugger ${ }^{1} \cdot$ Manfred Walzl $^{1} \cdot$ Andrew N. Ostrovsky $^{2,3}$ (1)
}

Received: 28 November 2018 / Revised: 19 February 2019 / Accepted: 21 February 2019 / Published online: 19 March 2019

(c) The Author(s) 2019

\begin{abstract}
Matrotrophy and its most advanced mode—placentation—is a masterpiece of nature contributing to offspring fitness. It has been studied mainly in vertebrates, whereas so-called placental analogues in invertebrates are poorly known. Here we use an ultrastructural approach to report the first evidence of placentation in the ctenostome bryozoan Amathia verticillata. This marine colonial suspension-feeder incubates its progeny in the tentacle sheath, which is transformed into a brood chamber. When the fertilized egg is deposited into the brood cavity, the tentacle sheath wall, originally consisting of flattened epithelial cells, is modified into an embryophore (placental analogue) via cell multiplication and hypertrophy. The embryophore (nutritive) cells develop a massive secretory apparatus and acquire 'microvillous' apical membranes indicating the presence of exocytosis. In turn, the embryo surface cells also form a complex network of irregular projections and foldings. Coated pits beneath this network indicate active endocytosis. The developing embryo is adjacent to the embryophore and the narrow slit between them is filled with dense and flocculent (presumably nutritive) material. The embryo increases up to 24-fold in size indicating substantial matrotrophic provisioning. We compare the ultrastructural details of placentation in A. verticillata with those known in cheilostome bryozoans, and review the major structural principles of placentation in Bryozoa in general. We then discuss possible ways of nutrient transport to the embryophore in various bryozoan clades.
\end{abstract}

Keywords Matrotrophy $\cdot$ Placenta $\cdot$ Brooding $\cdot$ Aquatic colonial invertebrates $\cdot$ Vesicularioidea

\section{Introduction}

Extraembryonic nutrition (EEN) or matrotrophy is a continuous extra-vitelline provisioning of offspring during gestation. Various modes of EEN have evolved in both, vertebrates and invertebrates with placentation (placentotrophy) being structurally the most complex and one of the most effective modes (Blackburn 2015; Ostrovsky et al. 2016). Vertebrate placentas and their analogues in invertebrates involve an intimate direct apposition or fusion of embryonic

Andrew N. Ostrovsky

oan_univer@yahoo.com

1 Department of Integrative Zoology, Faculty of Life Sciences, University of Vienna, Althanstraße 14, 1090 Vienna, Austria

2 Department of Invertebrate Zoology, Faculty of Biology, Saint Petersburg State University, Universitetskaja nab. 7/9, 199034 Saint Petersburg, Russia

3 Department of Palaeontology, Faculty of Earth Sciences, Geography and Astronomy, University of Vienna, Althanstraße 14, 1090 Geozentrum, Vienna, Austria tissues to the maternal ones providing/facilitating a bidirectional transfer of substances, nutrients and waste metabolites (Mossman 1937; Ostrovsky et al. 2016). Placentation is best known in mammals, reptiles, fishes and certain other chordates (e.g. salps) (Bauchot 1965; Wourms 1981; Bone et al. 1985; Blackburn 1999, 2005, 2015; Wooding and Burton 2008), but recently it was found to be rather common among invertebrates as well (Ostrovsky et al. 2016). Some placental analogues in Onychophora and Insecta resemble simple vertebrate placentae, representing striking examples of convergent evolution (Hagan 1951; Campiglia and Walker 1995).

Among aquatic invertebrates, Bryozoa has the widest within-phylum taxonomic distribution of placental analogues; these have evolved multiple times in various lineages (Ostrovsky et al. 2009a; Ostrovsky 2013a, b). This group of colonial suspension-feeders is classified into three clades: the non-calcified Phylactolaemata, which represent a small group of about 80 species living in freshwater, the exclusively marine, calcified Stenolaemata comprising approximately 600 recent species of the taxon Cyclostomata and the Gymnolaemata which constitute the largest part of over 
5000 currently described species (Bock and Gordon 2013). The Gymnolaemata are further divided into the uncalcified paraphyletic 'Ctenostomata' and the calcified Cheilostomata. Only about 300 species of recent ctenostomes are described, whereas the bulk of the species diversity of gymnolaemates is cheilostomes. All studied phylactolaemates and cyclostomes are placental, and more than 130 placental species are known among various gymnolaemate taxa (reviewed in Ostrovsky 2013a; Ostrovsky et al. 2016).

Indications of placentotrophy include the development of temporary nourishing structure(s) formed by the parent (and sometimes the offspring) during incubation, and ultrastructural evidence of nutrient release and uptake accompanied by enlargement of the embryo. Cheilostome bryozoans are better studied in this respect because both anatomical and ultrastructural evidence of placentation has been obtained during the last 100 years for a number of species (reviewed in Ostrovsky 2013a). Placental analogues were studied only anatomically in phylactolaemates and cyclostomes (reviewed in Reed 1991; Mukai et al. 1997). In the case of Ctenostomata, evidence of matrotrophy and placental analogues is so far mostly based on the embryonic size increase recorded in nine species. Nonetheless, the significance of this has not been fully understood or simply ignored (e.g., Braem 1939; Silén 1944). Except for a short note published in Russian (Ostrovsky and Schwaha 2011), no anatomical or ultrastructural analysis of the respective structures and mechanisms is available for ctenostomes. To compare the latter situation with placentation in other matrotrophic bryozoans, we analyzed the extraembryonic nutrition in Amathia (Zoobotryon) verticillata, a cosmopolitan vesicularioidean ctenostome. Sexual reproduction and larval development of this species were previously studied in detail (Bogoiavlenskii 1905; Waters 1914; Zirpolo 1933), including a description and illustration of the embryo size increase during development. Moreover, Bogoiavlenskii suggested an extraembryonic nourishment. We confirm this suggestion here, review the distribution and evolution of matrotrophy among ctenostomes and comparatively analyze this phenomenon in other bryozoan clades.

\section{Materials and methods}

Reproducing colonies of Amathia verticillata (delle Chiaje 1822) (Ctenostomata, Vesicularioidea) carrying embryos of different developmental stages were collected by wading at the shore of Rovinj, Croatia, in July, 2010. The long, 'spaghetti'-like colonies were cut into smaller pieces prior to fixation in $2.5 \%$ glutaraldehyde in $0.1 \mathrm{M}$ sodium-cacodylate buffer containing $10 \%$ sucrose $(\mathrm{pH}=7.4)$ for $1 \mathrm{~h}$ at room temperature. After fixation, the samples were rinsed three times in the buffer. Postfixation was conducted with $1 \%$ osmiumtetroxide for $1 \mathrm{~h}$ at room temperature. Specimens were then washed three times in the buffer prior to dehydration with acidified 2,2-dimethoxypropane or a graded acetone series. Dehydrated samples were embedded into Agar Low Viscosity Resin (Agar Scientific, Stansted, England) using acetone as intermedium. Cured resin blocks were concomitantly sectioned with a Reichert S-Cut or a Leica UC6 ultramicrotome (Leica Microsystems, Wetzlar, Germany) for semithin $(1 \mu \mathrm{m})$ to ultrathin $(60-70 \mathrm{~nm})$ sections. Semithin sections were collected on standard glass microscope slides, stained with toluidine blue, sealed with resin and then analyzed and photographed with a Nikon Eclipse E800 (Nikon, Tokyo, Japan) light microscope equipped with a Nikon DS-Fi2 U3 microscope camera. Ultrathin sections were collected on copper mesh-grids, stained with uranyl acetate for $40 \mathrm{~min}$ and afterwards with lead citrate for 5-10 min. Stained sections were analyzed with a Zeiss EM902 (Zeiss, Oberkochen, Germany) transmission electron microscope equipped with a digital CCD camera. Images were enhanced with Adobe Photoshop CS5 (Adobe Systems Incorporated, 345 Park Avenue, San Jose, CA). We should admit that zooidal coelom is strongly reduced because of shrinkage and folding of the thin cystid wall during dehydration of fixed material and its preparation for embedding in plastic. This did not affect tissues or cell ultrastructure, however.

A total of 15 fertile zooids, with ovaries and brooded embryos, were sectioned for both light and transmission electron microscopy (TEM). Twenty embryos of various ages were measured in fixed colonies to find the smallest and the largest stages and to calculate the embryo size increase.

\section{Results}

\section{Oogenesis, oviposition and brooding}

Colonies of Amathia verticillata consist of ellipsoid and oval autozooids located in dense groups along thick cylindrical stolons (Figs. 1, 2). Swollen brooding zooids are larger than non-brooding ones (Figs. 1, 2a-c). Early oocytes (size 21.9-23.1 $\times 43.9-50.0 \mu \mathrm{m}$ in our sections) were detected in pairs in the ovary, which is situated in the lower part of fertile zooids (Fig. 3a). Mature oocytes were not present in our material, but we found an aborted early embryo (gastrulastage, $52 \times 65 \mu \mathrm{m}$ ) surrounded by a fertilization envelope in a stolon (Fig. 3b). Judging from its appearance, the relatively small eggs are mesolecithal in this species.

Oogenesis is accompanied by partial degeneration of the polypide. Whereas the tentacle crown (Figs. 1, 3d), gut and retractor muscles degrade to a brown body (Figs. 1, 2a, b, d, $3 a)$, the thin-walled tentacle sheath and the vestibular wall with its four apertural muscles persist (Figs. 1, 2a, b, d, 3d, e, h). After fertilization (presumably near ovulation) the oldest 


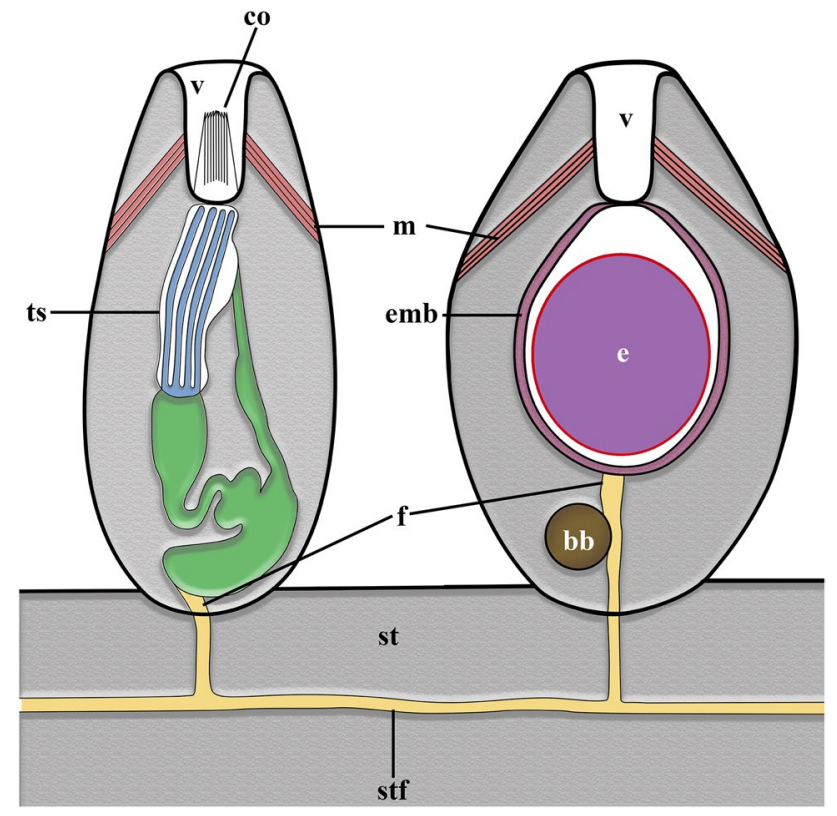

Fig. 1 Schematic drawing of sterile autozooid with retracted polypide and brooding female zooid on stolon. $b b$ brown body, co collar, $e$ embryo, emb embryophore, $f$ funiculus, $m$ apertural muscles, st stolon, $s t f$ stolonal funicular cord, $t s$ tentacle sheath, $v$ vestibulum

mature oocyte is transferred into the tentacle sheath which becomes a brood chamber that is isolated from the zooidal body cavity. The proximal side of the tentacle sheath, which contains the embryo, is now connected with a thick and short funicular cord going to the stolon to join its funicular system (Figs. 1, 2d and insert). The apertural muscles attached to the vestibular wall are probably important in larval release.

During incubation the embryo grows significantly and becomes a larva that occupies about half of the zooidal cavity (Fig. 2a-c). The tentacle sheath increases in size correspondingly. The smallest brooded embryo measured $71 \times 100 \mu \mathrm{m}$. The largest larvae reached $233-246 \mu \mathrm{m}$ in diameter. Thus, the embryonic enlargement was more than 24-fold.

\section{Extraembryonic nourishment}

\section{Early stage}

Further cleavages yield a hollow early embryo (Fig. 3c). The embryonic surface is closely adjoined to the tentacle sheath wall, which becomes a thickened, nourishing epithelium (embryophore). Originally small and flattened (3-4 $\mu \mathrm{m}$ thick in sections) (Fig. 3d), the cells of the tentacle sheath hypertrophy, becoming cuboidal (Fig. 3c, e), and obviously multiply since two cells constituted the embryophore width in some instances. The cell height varies within the same tentacle sheath up to two times reaching 8-11 $\mu \mathrm{m}$. Each of these nutritive cells contains a large and active nucleus with a basal or central position. Also, histological sections reveal dark granules in their cytoplasm. The embryophore is underlined by a thin basal membrane (Fig. 3e) that separates it from the zooidal coelom (strongly reduced during preparation of the material for sectioning, see above). The epithelium of the body wall also possesses a basal membrane which is unusual for gymnolaemate bryozoans (Fig. 5c).

The ultrastructure of the nutritive cells shows an extensive synthetic machinery. The largest part is the rough endoplasmatic reticulum (RER), which fills most of the cytoplasm in some cells (Fig. 4a). Numerous free ribosomes are evenly distributed within the cytoplasm. We also detected large presumably protein platelets with electron-dense, homogeneous content, lipid droplets, abundant mitochondria, multivesicular-like bodies, Golgi complexes and rare autophagosomes in the cells (Fig. $4 \mathrm{a}$ and insert, c). Most of the apical membrane in the nutritive cells is covered by numerous projections and shallow infoldings that give it an irregular 'microvillous' appearance; this strongly increases the surface area towards the embryo (Fig. 4). Non-folded areas are rare. Small electron-lucent vesicles (sometimes in stacks) are present underneath the membrane; some of these fuse with the latter (Fig. 4d, e), suggesting exocytosis.

The embryo is surrounded by a thin fertilization envelope (Fig. 4b-e). The superficial cells of the embryo also form numerous projections and infoldings. These, however, are often much longer and deeper than those observed in the embryophore cells and sometimes even form threedimensional labyrinths (Fig. 4b, e). In some instances, the deep folds/slits are formed parallel to the apical cell surface (Fig. 4c). Structures reminiscent of coated pits and a complex network of projections and infoldings suggest an active transport of nutrients. The cytoplasm of the superficial cells of the embryo contains abundant mitochondria and yolk granules (larger, electron-lucent proteinaceous platelets and smaller, electron-dense lipid droplets). Multivesicularlike bodies and cisterns of the RER are occasionally present. Ribosomes are abundant and mostly distributed non-evenly in the cytoplasm.

The narrow space between the embryophore and the embryonic cells is filled with massive flocculent or homogenous (supposedly, nutritive) material that is visible on both sides of the fertilization envelope, which therefore is apparently permeable for this substance (Fig. 4).

\section{Mid-stage}

Further embryonic development is accompanied by changes in the structure of the embryophore (Figs. 3f, 5). The nutritive cells thicken, become trapezoidal and extend to 14-14.5 $\mu \mathrm{m}$ height (Fig. 3f). Some cells show a clear polarity, with the RER situated in the basal part 

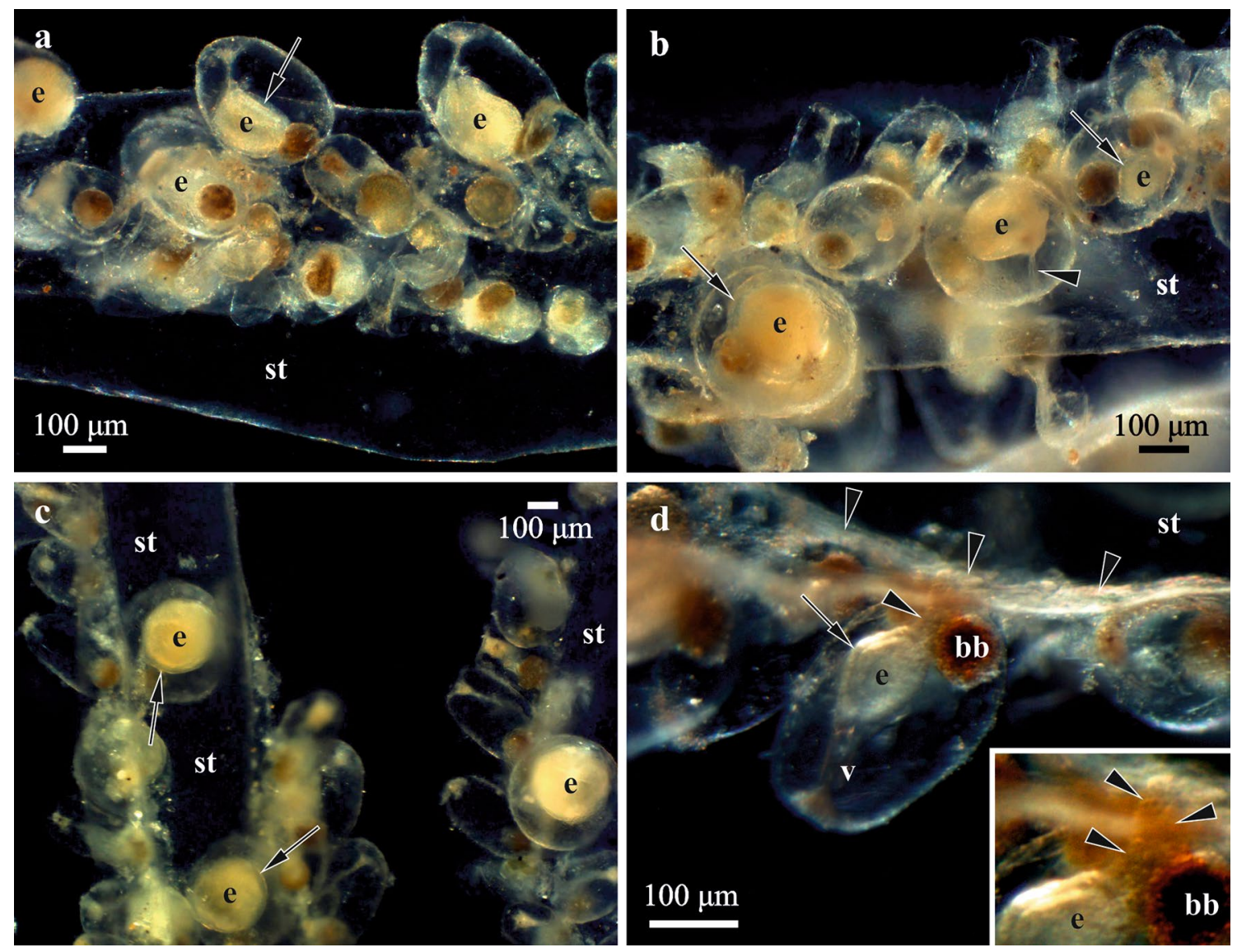

Fig. 2 Branch fragments of a fixed fertile colony of Amathia verticillata bearing zooids with embryos at various developmental stages. a Lateral view of colony fragment showing group of zooids on a stolon; embryos are incubated in four larger brooding zooids. b Upper view of colony fragment showing embryos in three brooding zooids. The smallest and youngest embryo is situated in the zooid to the right, the largest is visible to the left. Arrowhead indicates the apertural muscle. c Upper view of two colony fragments showing late embryos in three brooding zooids. d Close-up of brooding zooid containing early embryo. The tentacle sheath is connected with a stolonal funicular cord by the short funicular cord, enlarged in the insert (all cords shown by arrowheads). In all fragments, most zooids also contain degenerated or degenerating polypides (brown bodies) of various sizes. In all images, arrows point to wall of brood chamber (modified tentacle sheath). $b b$ brown body, $e$ embryo, st stolon, $v$ vestibulum

embryophore and the embryo is filled with homogeneous material.

\section{Late stage}

During the continuous embryonic enlargement, the embryophore thickness decreases to 6-9 $\mu \mathrm{m}$ (Figs. 3g, h, 6a). Nonetheless, its cells still show a very high synthesis and transport activity. Their cytoplasm is filled with RER cisterns that are tightly packed and fill most of the cytoplasm (Fig. 6a, b). Numerous proteinaceous platelets and incidental lipid droplets are visible apically and basally. Numerous mitochondria and vesicles containing flocculent 


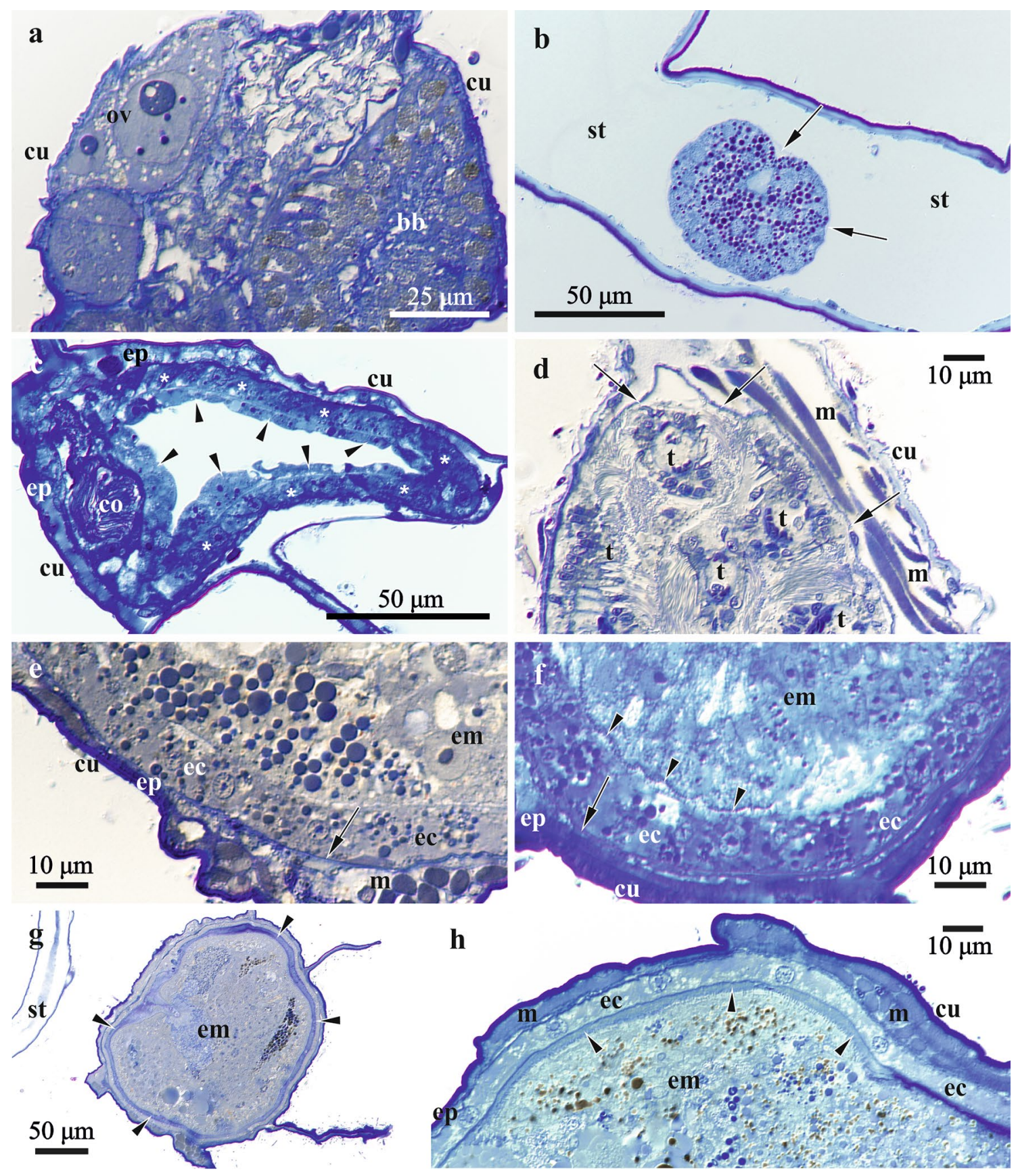

Fig. 3 Histological sections of fertile zooids of Amathia verticillata. a Cross-section of proximal part of autozooid mostly occupied by degenerating polypide (brown body) and ovary opposed to it. Ovary (to the left) contains two growing oocytes of various sizes. b Early abortive embryo in stolon (arrows point to fertilization envelope). c Oblique section of brooding zooid with early embryophore (asterisks) enveloping a hollow embryo (arrowheads). Shrunken cystid wall shows some folds. d Oblique section through the upper part of nonbrooding autozooid with non-modified tentacle sheath wall (indicated by arrows) enveloping tentacles. e Cross-section of brooding zooid showing area of early embryophore opposed to early embryo. Large yolk granules visible in the embryonic cells and the smaller granules in the embryophore cells. In fixed material zooidal coelom is slit- like and seen in some areas between the basal membranes (arrow) of embryophore and epithelium of cystid wall. $\mathbf{f}$ Cross-section of brooding zooid showing mid-stage embryophore and embryo with forming cilia (arrowheads); arrow points to basal membrane of embryophore. g Cross-section through brooding zooid largely filled with late embryo (cilia indicated by arrowheads). h Close-up of late embryophore and late embryo with well-developed cilia (arrowheads). In c, e-h zooidal coelom is strongly reduced because of deformation (folding) of cystide wall. Epithelium of cystid wall is very thin. $b b$ brown body, co collar, $c u$ cuticle of zooidal wall, ec embryophore cells, em embryo, $e p$ epithelium of zooidal wall, $m$ apertural muscle bundle, $o v$ ovary, $s t$ stolon, $t$ tentacle 

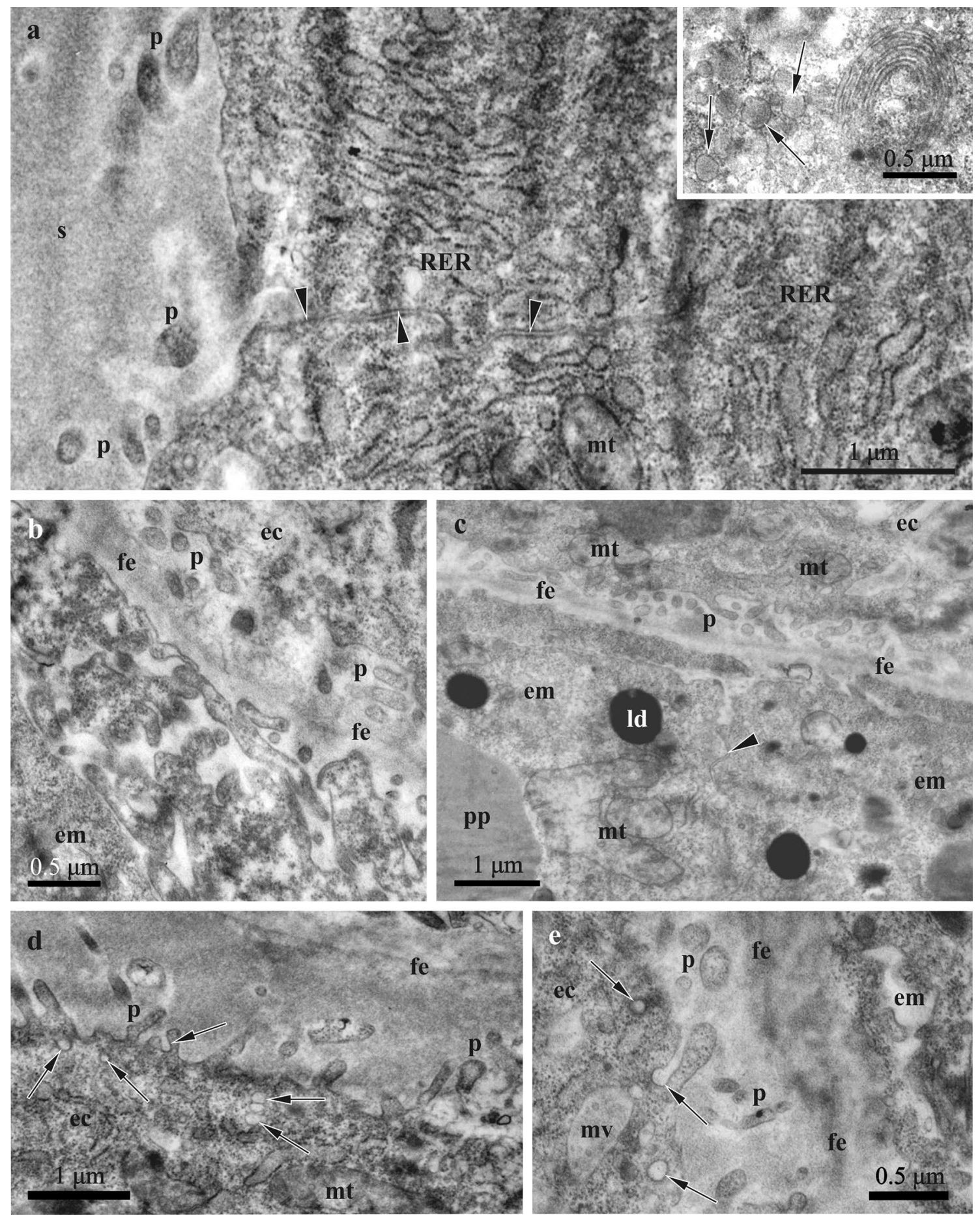

Fig. 4 Embryophore and embryo at early stage of incubation in Amathia verticillata (TEM). a Apical parts of two embryophore (nutritive) cells (opposed membranes shown by arrowheads) with almost non-folded membrane and already well developed rough endoplasmatic reticulum (RER) (embryo not visible); insert: Golgi complex with numerous microvesicles shown by arrows. b Opposed apical membranes of embryo (below) and embryophore cells with dense network of infoldings and microvillous projections, and fertilization envelope in-between. c Embryo (below) and embryophore cells with fertilization envelope in-between. The apical membrane of embryo cells shows wide horizontal infoldings with most of the cell surface being smooth (arrowheads indicate intercellular membranes). d, e Close-up of embryophore cell apical membrane showing details of exocytotic activity (arrows indicate stages of vesicle fusion with apical membrane). In all images the slit-like space between embryophore and embryo is filled with either homogenous or flocculent material (supposedly nutritive). ec embryophore cell, em embryo cell, $f e$ fertilization envelope, $l d$ lipid droplet, $m t$ mitochondria, $m v$ multivesicular-like body, $p$ projections of apical cell membrane of embryophore, $p p$ proteinaceous platelet, RER cisterns of rough endoplasmic reticulum, $s$ space between embryophore and embryo 

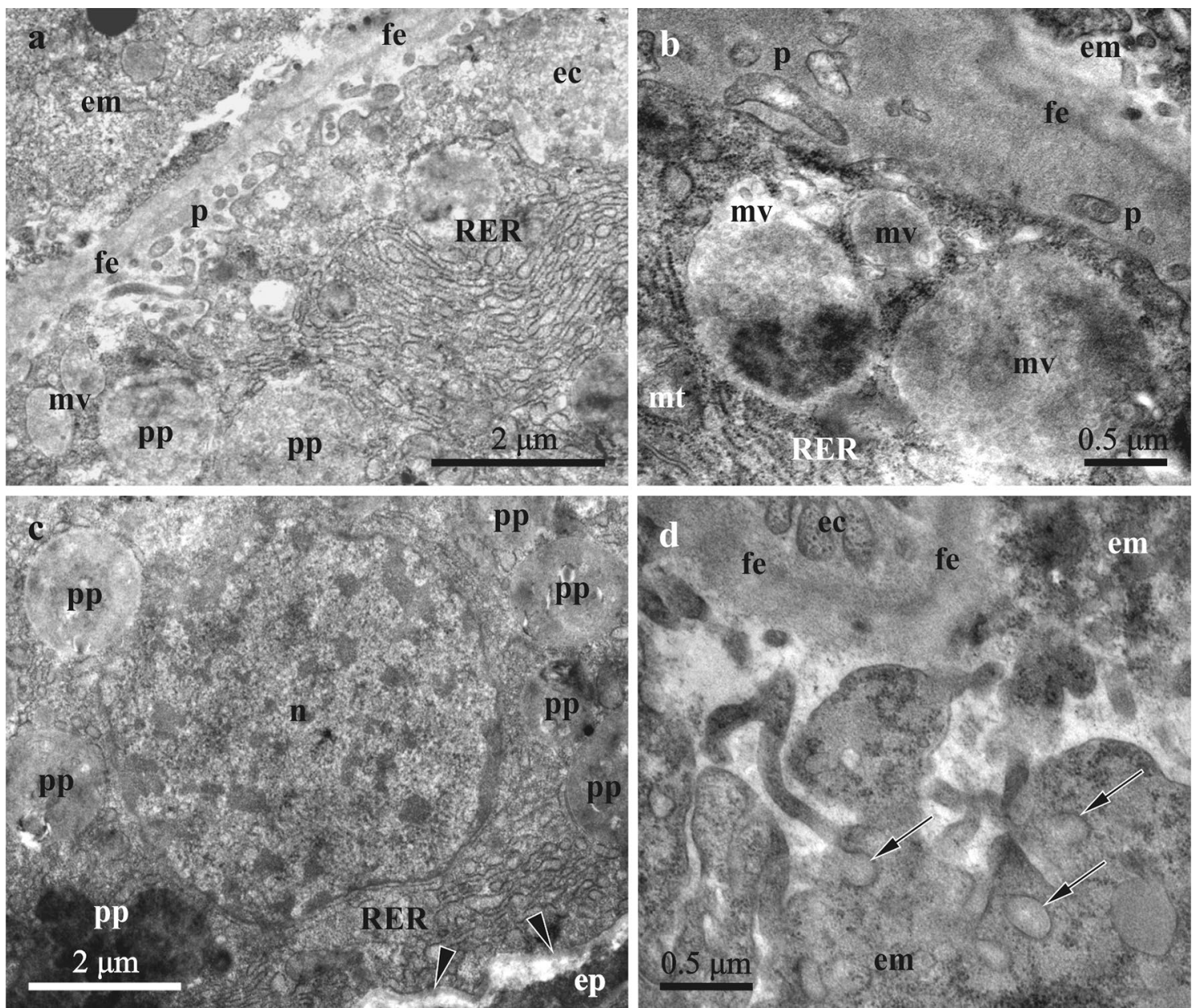

Fig. 5 Details of embryophore and embryo at mid-stage of incubation in Amathia verticillata (TEM). Apical (a) and basal (c) parts of embryophore cell with strongly developed RER and numerous proteinaceous platelets. In c nucleus shows heterochromatin scattered throughout the nucleoplasm (basal membrane shown by arrowheads). b Embryophore (below) and embryo cells with fertilization envelope in-between. Three multivesicular-like bodies visible underneath the apical membrane of nutritive cell. d Close-up of embryo cell apical

material are located underneath the apical cell membrane (Fig. 6b, d, f). Both smooth and folded apical membrane areas are visible in the nutritive cells. In addition, their membrane sometimes exhibits a fine microvillous appearance, either 'chaotic' or with a dense parallel packing of thin microvilli (Fig. 6d and insert). An important distinction is the presence of numerous autophagosomes in many embryophore cells (Fig. 6b). These cells sometimes overlap, giving the impression of two cell layers.

The space between the embryophore and the late embryo is mostly occupied by cilia of the late embryo (Figs. 3g, h, 6a, b) together with homogenous material that fills the space between the embryophore cells and the tips of the cilia (Fig. 6d, f). In its turn, the flocculent material fills the spaces between the cilia (Fig. 6c). The membrane showing details of endocytotic activity (arrows indicate coated pits). Tips of embryophore cell projections visible above. In a, $\mathbf{b}$ and $\mathbf{d}$ the slit-like space between embryophore and embryo is filled with either homogenous or flocculent material. ec embryophore cell, em embryo cell, ep epithelial cell of zooidal wall, $f e$ fertilization envelope, $m t$ mitochondria, $m v$ multivesicular-like body, $n$ nucleus, $p$ projections of embryophore apical cell membrane, $p p$ proteinaceous platelet, RER cisterns of rough endoplasmic reticulum

fertilization envelope is closely apposed to the embryophore. It is indiscernible in some areas, possibly destroyed. Numerous microvilli are developed between the bases of the cilia, with coated pits present between the bases of microvilli (Fig. 6c, e).

\section{Discussion}

\section{Evidence of matrotrophy in Amathia verticillata}

Our results demonstrate substantial matrotrophic nourishment in Amathia verticillata. All three lines of evidenceanatomical, ultrastructural and dimensional-support this conclusion. In general, the anatomical evidence of 

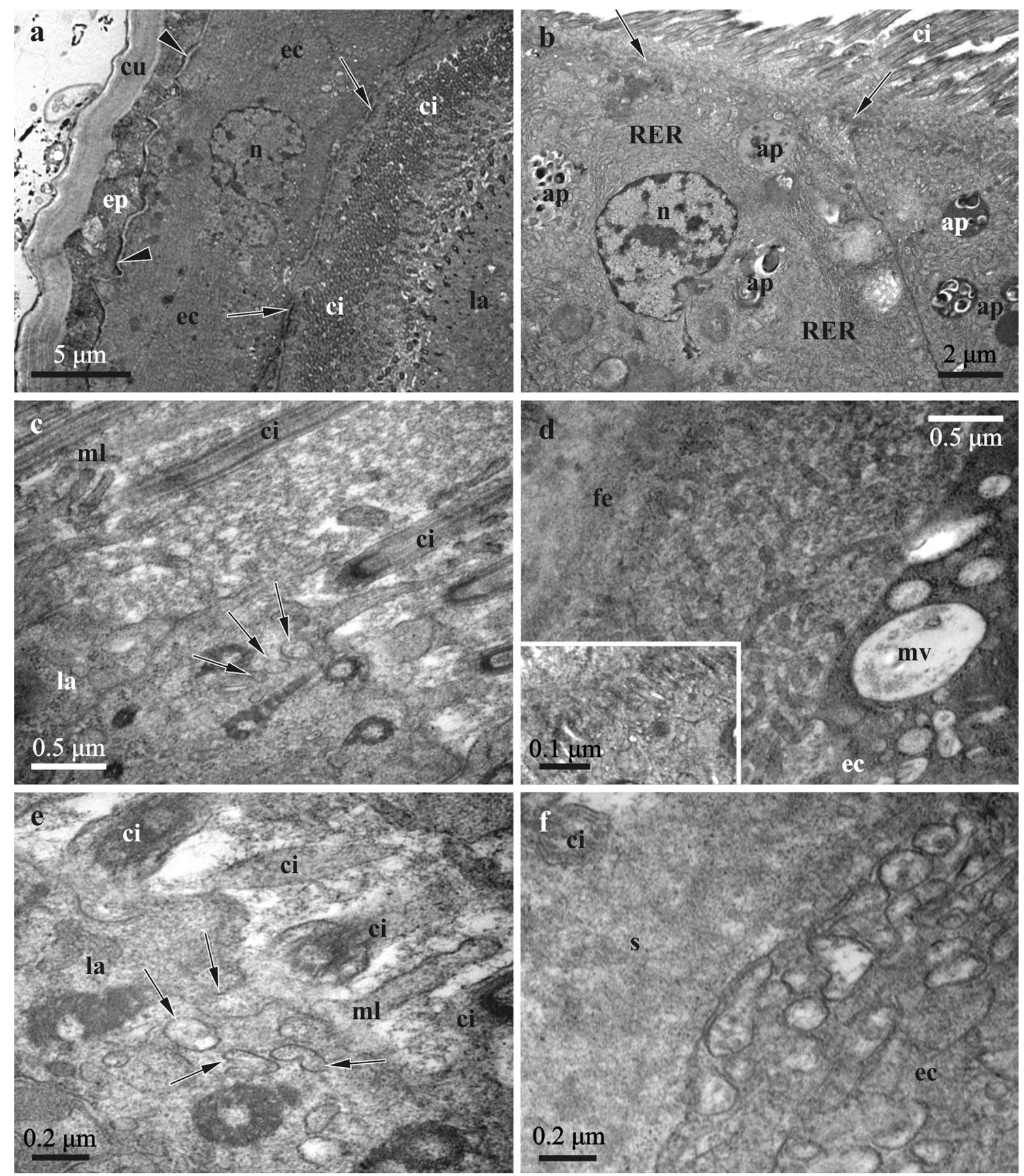

Fig. 6 Details of embryophore and embryo at late incubation stage in Amathia verticillata (TEM). a Zooidal wall and embryophore adjacent to early larva (slit-like zooidal body cavity shown by arrowheads; arrows indicate fertilization envelope). b Apical parts of embryophore cells opposed to larval ciliature. Numerous autophagosomes are visible in the cytoplasm (arrows indicate fertilization envelope). c, e Close-ups of apical membrane of larval cell showing cilia bases, microvilli and endocytotic vesicles (arrows). Spaces between cilia are filled by flocculent material. d Close-ups of apical membrane of embryophore cell with dense network of microvillous

projections and cisternae of RER and various vesicles beneath, presumable indicating active exocytosis (insert shows parallel microvilli of the apical membrane in another cell). f Close-ups of apical membrane of embryophore cell with various vesicles beneath indicating active exocytosis. In all images the space between embryophore and larval cilia is filled mostly with homogenous material. ap autophagosome, $c i$ cilia, ec embryophore cell, em embryo cell, ep epithelial cell of zooidal wall, $\mathrm{fe}$ fertilization envelope, $l a$ larva, $m l$ microvilli, $m v$ multivesicular-like body, $n$ nucleus, $R E R$ cisterns of rough endoplasmic reticulum, $s$ space between embryophore and larva 
placentation involves the formation of temporary structure(s) (presumably providing gas exchange and nourishment) associated with the incubation chamber when it contains an embryo. After release of the offspring these structures degenerate, indicating that the incubation itself triggers their formation and persistence. In A. verticillata the strong hypertrophy and presumed multiplication of the tentacle sheath cells during incubation indicate their role as a placental analogue. Since the polypide degenerates in the brooding zooid and it can not feed itself, the transport of nutrients should be provided from the remaining colony via the elaborate funicular system characterizing Vesicularioidea (e.g., Bobin 1977). The funicular cord initially connects the gut of the functional polypide with colonial funicular strand in the stolon and thus supposedly transports nutrients to the colony. Upon polypide degeneration and oviposition to the tentacle sheath the cord becomes associated with the proximal side of the brood chamber (Bogoiavlenskii 1905; Zirpolo 1933). Here, the direction of transport should be reversed. It is also possible that the degenerating polypide (brown body) is a source of nutrients during oogenesis as well as brooding (see, e.g., Hastings 1932; Ostrovsky 2013a).

Importantly, Bogoiavlenskii (1905) was the first to suggest extraembryonic nutrition in A. verticillata. While some of his speculations were incorrect (e.g., he thought that the 'embryonic sheath' [embryophore] is developed from several funicular cells entering the tentacle sheath during oviposition), he correctly described many details of brooding including the multiplication of the embryophore cells and their transformation from cuboidal to flattened in the late stages of incubation. He also noted the appearance of granules in the funiculus (also mentioned by Waters 1914). Bogoiavlenskii suggested that the egg moves to the tentacle sheath when the gut of the degenerating polypide detaches from the tentacle sheath. Between the funicular and embryophore cells he described a 'continuous homogeneous whitish mass' that he thought to be the nutrients produced and delivered by the cells of the funiculus, absorbed by the cells of the 'embryonic sheath', and further released to the brood cavity (Bogoiavlenskii 1905, p. 12). Suggesting EEN, Bogoiavlenskii stressed, however, that the embryo is not attached to the embryophore wall and that there is no a placental contact as described for phylactolaemates.

The ultrastructural evidence includes the development of a massive secretory apparatus (including RER and Golgi complexes) in the embryophore cells, the formation of numerous projections and infoldings as well as microvillilike outgrowth of the apical cell membrane and transport vesicles fusing with the latter. Together with the presence of homogenous and flocculent material in the space between the brood chamber wall and the embryo, these facts indicate an active production and release of nutrients via exocytosis. Note, however, that some of the vesicles were similar to coated pits, thus indicating endocytosis (of the embryo's waste products), too. The surface cells of the embryos and larvae show a corresponding modification and exhibit a complex network of infoldings and microvilli together with the formation of coated pits. Similar trophic modifications were recorded in the studied cheilostome bryozoans (Woollacott and Zimmer 1975; Hughes 1987; Moosbrugger et al. 2012; Nekliudova et al. 2019). In contrast to A. verticillata, the thick cuticle of the body wall separates the embryophore cells from the brood cavity in the Cheilostomata. It is, however, permeable for nutrients.

The third line of evidence is a strong embryonic enlargement in A. verticillata as already described by earlier authors (Bogoiavlenskii 1905; Waters 1914; Zirpolo 1933). The substantial maternal provisioning normally results in a prominent growth/increase in embryo size. Although this evidence is indirect (in contrast to, e.g., the increase of dry weight, see Blackburn 2015; Ostrovsky et al. 2016 for discussion), the estimated 24-fold enlargement of the embryo and formation of the 'solid' larva in the studied species clearly indicate extraembryonic provisioning.

Our data on the early embryos found in histological sections and whole mounts differ to some extent, which could affect calculation of the embryonic enlargement during incubation. The diameter of the smallest brooded embryo we found in zooids was about $85 \mu \mathrm{m}$ (see above) (which also corresponds to the size of the mature egg calculated from Table I, Fig. 1 of Bogoiavlenskii 1905). The early aborted embryo found in a stolon was smaller (about $60 \mu \mathrm{m}$ in diameter). No strong decrease in egg size during fixation has ever been described in bryozoans (see, e.g., Ostrovsky 2013a), and the egg size variation could help to explain the abovementioned difference. Since no mature eggs were detected in our material and early embryos were very rare, further research is required to clarify this situation.

\section{Multiple origins of placentation among ctenostome bryozoans}

Parental care in form of embryo incubation has evolved several times among ctenostome Gymnolaemata (Ostrovsky 2013a). The simplest is external brooding of multiple embryos in membranous brood sacs attached to the body wall of the fertile zooid, which in some species is accompanied by temporary withdrawal of the embryos (in case if they are attached to vestibular wall) to the vestibule during polypide retraction. The more advanced variant is an immersion of the developing embryos into the vestibular or cystid wall (reviewed by Ström 1977). The acquirement of brooding in an invagination of the body wall triggered the evolution of matrotrophy in some ctenostomes, which is indicated by embryo size increase and hypertorphy of the cells of the brood chamber wall (or both). Embryo enlargement 
was recorded in three species of the genus Nolella (Hincks 1880; Prouho 1892; Harmer 1915). Cell hypertrophy was additionally observed in the brood chamber wall in Sundanella sibogae (Braem 1939) and Labiostomella gisleni (Silén 1944) (although the ctenostome affinity of the latter species is disputable). Another type of incubation is brooding inside the tentacle sheath. Incubated embryos become larger in four species (including A. verticillata) from four different ctenostome clades (Joliet 1877; Bogoiavlenskii 1905; Pace 1906; Waters 1914; Zirpolo 1933; Banta 1968). A further incubation mode in a special outer embryo sac is known in certain boring ctenostomes. No EEN has been previously detected in this case, however (reviewed in Ström 1977; Ostrovsky 2013a).

Considering the differences in the incubation mode, reproductive patterns and the current position of matrotrophic ctenostomes on the phylogenetic tree (Todd 2000), extraembryonic nutrition could have evolved five times in this group. This needs to be confirmed based on newer molecular phylogenies. EEN has evolved at least 16 times among cheilostomes and once each in phylactolaemates and cyclostomes (Ostrovsky 2013a, b). Despite such diversity, the main principles of placental analogue organization are the same throughout Bryozoa. Incubated embryos are surrounded, totally or partially, by temporarily hypertrophied nourishing cells that form the embryophore. Incubation in internal brood sacs-as known in some matrotrophic Cheilostomata (Ostrovsky et al. 2009b) and in presumably all Phylactolaemata (e.g., Braem 1890, 1897, 1908; Marcus 1934; Mukai 1982) - is analogous to the ctenostome brooding in body wall invaginations or the tentacle sheath. In gymnolaemates, the ectodermal epithelium of the maternal cystid forms a chamber surrounding an embryo from all sides, and both ecto- and mesodermal cells form this sac in phylactolaemates. Similarly, developing embryos are embedded into the placental analogue in Cyclostomata, but embryogenesis is preparative in this viviparous group, and the placenta is mesodermal (e.g., Harmer 1893, 1896, 1898; Borg 1926). A similar situation is present in the viviparous cheilostome family Epistomiidae (Marcus 1941; Dyrynda 1981; Dyrynda and King 1982). Finally, in most matrotrophic cheilostomes embryos are incubated in external brood chambers (ovicells) (e.g., Harmer 1902, 1926; Marcus 1938; Corrêa 1948; Woollacott and Zimmer 1972, 1975; Dyrynda and King 1983; Hughes 1987; Santagata and Banta 1996; Ostrovsky 1998, 2013a, b; Ostrovsky et al. 2008, 2009a; Moosbrugger et al. 2012). The embryophore is associated with a so-called ooecial vesicle-a contractile outfolding of the maternal body wall that plugs the entrance to the brood cavity. In this case, the embryo is only partially surrounded by the placental analogue.

We stress here that the oviposited egg is often much smaller than the incubation cavity. Thus, the initial and the following stages of embryonic nourishment are supported not by placentotrophy, but histotrophy-absorption of the nutrients by the embryo from the surrounding fluid. The progressive enlargement of the offspring during its development results in total occupation of the brood cavity. This is accompanied by an opposition of the embryo surface to the embryophore, which is formally considered as placentation (Mossman 1937).

In Phylactolaemata, Cyclostomata and most matrotrophic 'Ctenostomata' the nutrients required for embryonic development are supposedly obtained by the placenta from the surrounding fluid of the maternal body cavity. In the placental Cheilostomata and A. verticillata they are obviously transported via a funicular system whose cord(s) are associated with the embryophore (Woollacott and Zimmer 1975; Moosbrugger et al. 2012; Nekliudova et al. 2019; our data). In cheilostomes, the nutritive cells of the embryophore at the advanced stage are mainly covered by funicular cells; their multiplication points to an intense transport.

\section{Conclusion}

The degree of matrotrophic provisioning varies strongly, ranging from negligible to high in different taxa. This presumably reflects an evolutionary trend towards a transition from incipient to substantial matrotrophy (Blackburn 2015). Among bryozoans such a variation is especially well documented within Cheilostomata (reviewed in Ostrovsky 2013a, b). The ctenostomes are strongly understudied in this respect, but in two species-Sundanella sibogae and Amathia verticillata (Braem 1939; our data)—morphological evidence clearly points to a very high level of maternal provisioning by well developed placental analogues.

The taxon-wide distribution of placentation among bryozoans is remarkable. In this respect these colonial filterfeeders are outnumbered only by chordates, platyhelminths and arthropods (Ostrovsky et al. 2016). Bryozoans are very diverse structurally and ecologically (McKinney and Jackson 1989; Ryland 2005), and they also exhibit a wide spectrum of reproductive patterns including larval planktotrophy, lecithotrophy, and matrotrophy (Reed 1991; Ostrovsky 2013a). The selective pressures that could explain the multiple origins of placentation are unknown, but placentation potentially could play an important role in the evolutionary success of the ancient taxon Cyclostomata. In this clade the origin of EEN presumably stimulated the acquisition of polyembryony and sexual zooidal polymorphism (Ostrovsky 2013b). Their evolution in the late Triassic was followed by a long-term increase in cyclostome diversity (Jablonski et al. 1997). The only cyclostomes without gonozooids are Cinctiporidae, but placentation is conceivable inside their very large autozooids (Schwaha et al. 2018). In the 
Gymnolaemata placentation is known mostly in species with ephemeral erect colonies/colony parts. A possible benefit of EEN is accelerated larval production because embryonic growth and development occur simultaneously in matrotrophic species (Ostrovsky et al. 2009a). This interpretation needs to be confirmed by analyzing a wider range of both cheilostomes and ctenostomes.

Acknowledgements Open access funding provided by University of Vienna. We thank the Department for Cell Imaging and Ultrastructure Research, University of Vienna, and especially Daniela Gruber, for the use of the electron microscope facility. Dr M. Stachowitsch, University of Vienna, revised an early draft of the manuscript and improved its English. Two anonymous reviewers greatly helped to revise the text.

Funding This study was funded by the Austrian Science Fund (grant $\mathrm{P}$ 22696-B17) (microscopy) and the Russian Science Foundation (grant 18-14-00086) (data processing and MS preparation).

\section{Compliance with ethical standards}

Conflict of interest All authors declare that they have no conflict of interest.

Ethical approval All applicable international, national, and/or institutional guidelines for the care and use of animals were followed. This article does not contain any studies with human participants performed by any of the authors.

Open Access This article is distributed under the terms of the Creative Commons Attribution 4.0 International License (http://creativeco mmons.org/licenses/by/4.0/), which permits unrestricted use, distribution, and reproduction in any medium, provided you give appropriate credit to the original author(s) and the source, provide a link to the Creative Commons license, and indicate if changes were made.

\section{References}

Banta WC (1968) Mimosella cookae, new species (Bryozoa, Ctenostomata) with a review of the family Mimosellidae. Bull South Calif Acad Sci 67:245-254

Bauchot R (1965) La placentation chez les reptiles. An Biol 4:547-575

Blackburn DG (1999) Placenta and placental analogs in reptiles and amphibians. In: Knobil E, Neill JD (eds) Encyclopedia of reproduction. Academic Press, New York, pp 840-847

Blackburn DG (2005) Amniote perspectives on the evolution of viviparity and placentation. In: Grier H, Uribe MC (eds) Viviparity in fishes. New Life Publications, Homestead, pp 301-322

Blackburn DG (2015) Evolution of vertebrate viviparity and specializations for fetal nutrition: a quantitative and qualitative analysis. $\mathrm{J}$ Morphol 276:961-990. https://doi.org/10.1002/jmor.20272

Bobin G (1977) Interzooecial communications and the funicular system. In: Woollacott RM, Zimmer RL (eds) Biology of bryozoans. Academic Press, New York, pp 307-333

Bock PE, Gordon DP (2013) Phylum Bryozoa Ehrenberg, 1831. Zootaxa 3703:67-74. https://doi.org/10.11646/zootaxa.3703.1.14

Bogoiavlenskii H (1905) To the knowledge of embryonic development, budding, and regeneration in Zoobotryon pellucidus Ehrbg. Izv Imp Ob Lub Est Antr Etnogr 108:1-90 [Transliterated from
Russian: Materialy k poznaniju embrional'nago razvitija, pochkovanija i regeneratsii Zoobotryon pellucidus Ehrbg. Izvestija Imperatorskago Obshchestva liubitelei estestvoznaniia, antropologii i etnografii]

Bone Q, Pulsford AL, Amoroso EC (1985) The placenta of the salp (Tunicata: Thaliacea). Placenta 6:53-63

Borg F (1926) Studies on recent cyclostomatous Bryozoa. Zool Bid Uppsala 10:181-507

Braem F (1890) Untersuchungen über die Bryozoen des süßen Wassers. Zoologica 6:1-134

Braem F (1897) Die geschlechtliche Entwicklung von Plumatella fungosa. Zoologica 23:1-96

Braem F (1908) Die geschlechtliche Entwicklung von Fredericella sultana nebst Beobachtungen über die weitere Lebensgeschichte der Kolonien. Zoologica 20:1-38

Braem F (1939) Victorella sibogae Harm. Z Morph Ökol Tiere $36: 267-278$

Campiglia SS, Walker MH (1995) Developing embryo and cyclic changes in the uterus of Peripatus (Macroperipatus) acacioi (Onychophora, Peripatidae). J Morphol 224:179-198. https://doi. org/10.1002/jmor.1052240207

Corrêa DD (1948) A embriologia de Bugula flabellata (J.V. Thompson) (Bryozoa Ectoprocta). Bol Fac Filosof Cien Let Univ São Paolo Zool 13:7-71

Delle Chiaje S (1822-1829). Memorie sulla storia e notomia degli animali senza vertebre dell regno di Napoli. Fratelli Fernand, Napoli

Dyrynda PEJ (1981) A preliminary study of patterns of polypide generation-degeneration in marine cheilostome Bryozoa. In: Larwood GP, Nielsen C (eds) Recent and fossil Bryozoa. Olsen and Olsen, Fredensborg, 73-81

Dyrynda PEJ, King PE (1982) Sexual reproduction in Epistomia bursaria (Bryozoa, Cheilostomata), an endozooidal brooder without polypide recycling. J Zool 198:337-352. https://doi. org/10.1111/j.1469-7998.1982.tb02080.x

Dyrynda PEJ, King PE (1983) Gametogenesis in placental and nonplacental ovicellate cheilostome Bryozoa. J Zool 200:471-492. https://doi.org/10.1111/j.1469-7998.1983.tb02810.x

Hagan HR (1951) Embryology of viviparous insects. Ronald Press, New York

Harmer SF (1893) On the occurrence of embryonic fission in cyclostomatous Polyzoa. Q J Microsc Sci 34:199-241

Harmer SF (1896) On the development of Lichenopora verrucaria FABR. Q J Microsc Sci 39:71-144

Harmer SF (1898) On the development of Tubulipora, and on some British and Northern species of this genus. Q J Microsc Sci 41:73-157

Harmer SF (1902) On the morphology of the Cheilostomata. Q J Microsc Sci 46:263-350

Harmer SF (1915) The Polyzoa of the Siboga expedition. Part 1. Entoprocta, Ctenostomata and Cyclostomata. Siboga Exped 28a:1-180

Harmer SF (1926) The Polyzoa of the Siboga expedition. Part 2. Cheilostomata Anasca. Siboga Exped 28b:183-501

Hastings AB (1932) The Polyzoa with a note on an associated hydroid. Sci Rep Gt Barrier Reef Exp 1928-29 4:399-458

Hincks T (1880) A History of the British Marine Polyzoa. Van Voorst, London

Hughes DJ (1987) Gametogenesis and embryonic brooding in the cheilostome bryozoan Celleporella hyalina. J Zool 212:691-711. https://doi.org/10.1111/j.1469-7998.1987.tb05965.x

Jablonski D, Lidgard S, Tayor PD (1997) Comparative ecology of bryozoan radiations: origin of novelties in cyclostomes and cheilostomes. Palaios 12:505-523. https://doi.org/10.2307/3515408

Joliet L (1877) Contribution à l'histoire naturelle des Bryozoaires des côtes de France. Arch Zool Exp Gen 6:193-304

Marcus E (1934) Über Lophopus crystallinus (PALL.). Zool Jahrb Abt Anat Ontog Tiere 58:501-606 
Marcus E (1938) Bryozoarios marinhos brasileiros. II. Bol Fac Filosof Cien Let Univ São Paolo Zool 2:1-196

Marcus E (1941) Sobre o desenvolvimento do bryozoario Synnotum aegyptiacum. Arq Cirurg Clin Exp 5:227-234

McKinney FK, Jackson JBC (1989) Bryozoan evolution. University of Chicago Press, Chicago

Moosbrugger M, Schwaha T, Walzl MG, Obst M, Ostrovsky AN (2012) The placental analogue and the pattern of sexual reproduction in the cheilostome bryozoan Bicellariella ciliata (Gymnolaemata). Front Zool 9:1-20. https://doi.org/10.1186/1742-9994-9-29

Mossman HW (1937) Comparative morphogenesis of the fetal membranes and accessory uterine structures. Carnegie Inst Washington Contr Embryol 26:129-246

Mukai H (1982) Development of freshwater bryozoans (Phylactolaemata). In: Harrison FW, Cowden RR (eds) Developmental biology of freshwater invertebrates. Alan R. Liss Inc., New York, pp 535-576

Mukai H, Terakado KY, Reed CG (1997) Bryozoa. In: Harrison FW (ed) Microscopic anatomy of invertebrates, vol 13. Wiley-Liss, Inc., New York, pp 45-206

Nekliudova UA, Schwaha TF, Kotenko ON, Gruber D, Cyran N, Ostrovsky AN (2019) Sexual reproduction of the placental brooder Celleporella hyalina (Bryozoa, Cheilostomata) in the White Sea. J Morphol 280:278-299. https://doi.org/10.1002/jmor.20943

Ostrovsky AN (1998) Comparative studies of ovicell anatomy and reproductive patterns in Cribrilina annulata and Celleporella hyalina (Bryozoa: Cheilostomata). Acta Zool 79:287-318. https ://doi.org/10.1111/j.1463-6395.1998.tb01280.x

Ostrovsky AN (2013a) Evolution of sexual reproduction in marine invertebrates: example of gymnolaemate bryozoans. SpringerVerlag, Dordrecht

Ostrovsky AN (2013b) From incipient to substantial: evolution of placentotrophy in aquatic colonial invertebrates. Evolution 67:13681382. https://doi.org/10.5061/dryad.b5k4s

Ostrovsky AN, Schwaha T (2011) Ultrstructure of the placental analogue in ctenostome bryozoan Zoobotryon verticillatum (Delle Chiaje, 1828) (Gymnolaemata). In: Zaitseva OV, Petrov AA (eds) Modern problems of evolutionary morphology of animals. Proceedings of the 2nd All-Russian and International Conference dedicated to the 105th anniversary of academician AV Ivanov. Zoological Institute of the Russian Academy of Sciences, Saint Petersburg, pp. 254-256 (in Russian)

Ostrovsky AN, Vávra N, Porter JS (2008) Sexual reproduction in gymnolaemate Bryozoa: history and perspectives of the research. In: Wyse Jackson PN, Spencer-Jones ME (eds) Annals of bryozoology 2: aspects of the history of research on bryozoans. International Bryozoology Association, Dublin, pp 117-210

Ostrovsky AN, Gordon DP, Lidgard S (2009a) Independent evolution of matrotrophy in the major classes of Bryozoa: transitions among reproductive patterns and their ecological background. Mar Ecol Prog Ser 378:113-124. https://doi.org/10.3354/meps07850

Ostrovsky AN, O'Dea A, Rodrígues F (2009b) Comparative anatomy of internal incubational sacs in cupuladriid bryozoans and the evolution of brooding in free-living cheilostomes. J Morphol 270:1413-1430. https://doi.org/10.1002/jmor.10767

Ostrovsky AN, Lidgard S, Gordon DP, Schwaha T, Genikhovich G, Ereskovsky AV (2016) Matrotrophy and placentation in invertebrates: a new paradigm. Biol Rev 91:673-711. https://doi. org/10.1111/brv.12189

Pace RM (1906) On the early stages in the development of Flustrella hispida (Fabricius), and on the existence of a "yolk nucleus" in the egg of this form. Q J Microsc Sci 50:435-478

Prouho H (1892) Contribution à l'histoire des Bryozaires. Arc Zool Exp Gen 10:557-656

Reed CG (1991) Bryozoa. In: Giese AC, Pearse JS, Pearse VB (eds) Reproduction of marine invertebrates: echinoderms and lophophorates. The Boxwood Press, Pacific Grove, pp 85-245

Ryland JS (2005) Bryozoa: an introductory overview. In: Woess E (ed) Moostiere (Bryozoa). Denisia, vol 16. Biologiezentrum, Oberösterreichisches Landesmuseum, Linz, pp 9-20

Santagata S, Banta WC (1996) Origin of brooding and ovicells in cheilostome bryozoans: interpretive morphology of Scrupocellaria ferox. Invert Biol 115:170-180. https://doi. org/10.2307/3227047

Schwaha T, Handschuh S, Ostrovsky AN, Wanninger A (2018) Morphology of the bryozoan Cinctipora elegans (Cyclostomata, Cinctiporidae) with the first data on its sexual reproduction and the cyclostome neuro-muscular system. BMC Evol Biol 18:92. https://doi.org/10.1186/s12862-018-1206-1

Silén L (1944) The anatomy of Labiostomella gisleni Silén (Bryozoa Protocheilostomata). K Sven Vetenskapsakad, Handl 3, 21:1-111

Ström R (1977) Brooding patterns of bryozoans. In: Woollacott RM, Zimmer RL (eds) Biology of bryozoans. Academic Press, New York, pp 23-55

Todd JA (2000) The central role of ctenostomes in bryozoan phylogeny. In: Herrera Cubilla A, Jackson JBC (eds) Proceedings of the 11th International Bryozoology Association conference. Smithsonian Tropical Research Institute, Balboa, p 104-135

Waters AW (1914) The marine fauna of British East Africa and Zanzibar from collections made by Cyril Crossland. Bryozoa-Cyclostomata, Ctenostomata and Endoprocta. Proc Zool Soc London 2:831-858

Wooding P, Burton G (2008) Comparative placentation: structures, functions and evolution. Springer-Verlag, Berlin

Woollacott RM, Zimmer RL (1972) Origin and structure of the brood chamber in Bugula neritina (Bryozoa). Mar Biol 16:165-170. https://doi.org/10.1007/BF00347954

Woollacott RM, Zimmer RL (1975) A simplified placenta-like system for the transport of extraembryonic nutrients during embryogenesis of Bugula neritina (Bryozoa). J Morphol 147:355-378. https ://doi.org/10.1002/jmor.1051470308

Wourms JP (1981) Viviparity: the maternal-fetal relationships in fishes. Amer Zool 21:473-515. https://doi.org/10.1093/icb/21.2.473

Zirpolo G (1933) Zoobothryon verticillatum (Delle Chiaje). Mem Pont Acc Sci 17:109-441

Publisher's Note Springer Nature remains neutral with regard to jurisdictional claims in published maps and institutional affiliations. 